\title{
Effect of Storage Period on Physio - Chemical Properties of Guava Fruit Leather
}

\author{
Shaik Jakeer Basha* \\ Department Food Science and Technology, Mahatma Phule Krishi Vidyapeeth, Rahuri, India \\ *Corresponding author
}

\begin{tabular}{|l|}
\hline Ke y w or d s \\
Guava, Lalith, \\
Sardar, Leather, \\
Storage \\
\hline Article Info \\
\hline Accepted: \\
12 March 2018 \\
Available Online: \\
10 April 2018 \\
\hline \hline
\end{tabular}

\section{Introduction}

Guava (Psidium guajava L.) is quite hardy, prolific bearer with sweet aroma and pleasant sour sweet taste, This is a member of dicotyledonous, belong to large member of Myrtaceae or Myrtle family believed to be originated in Central America and Southern part of Mexico (Somogyi et al., 1996). It is a small tree or shrub of 2 to $8 \mathrm{~m}$ in height with wide spreading branches (Singh, 1988). It is claimed to be the fourth most important cultivated fruit in area and production after mango, banana and citrus. India leads the world in guava production (Singhal, 1996). Crop in India occupies an area of 2.20 lack ha with annual production 25.72 lack MT having productivity 11.70 MT/ha (2010). Major 
guava producing states are Uttar Pradesh, Maharashtra, Bihar, Andhra Pradesh, Gujarat, Madhya Pradesh, and Karnataka. In Maharashtra Guava is an important commercial horticultural crop and stands $2^{\text {nd }}$ place in production with an area of 33,469 ha, produce of 2.58 lack MT and productivity 7.80 MT/ha (Bijay Kumar 2011). The quality and nutritional value of guava fruits are influenced by physical and biochemical changes during maturation by photosynthesis and accumulation. Fully mature guava fruits have very strong flavour therefore it is unsuitable to use as a table purpose. The fruit has about $83 \%$ moisture and is an excellent source of ascorbic acid $(100-260 \mathrm{mg} / 100 \mathrm{~g}$ pulp) and pectin $(0.5-1.8 \%)$ (Verma and Shrivastava, 1965), but has low energy (66 $\mathrm{Cal} / 100 \mathrm{~g}$ ) and protein content (1\%) (Bose et al., 1999). The fruit is rich in minerals like phosphorous (23-37 mg/100 g), calcium (14$30 \mathrm{mg} / 100 \mathrm{~g}$ ), iron (0.6-1.4 mg/100 g), as well as vitamins like Niacin, Pantothenic acid, Thiamine, Riboflavin, vitamin A (Bose et al., 1999). Whole fruit is edible along with skin, considered as one of most delicious and luxurious fruits, often marketed as "Super fruits" which has a considerable nutritional importance in terms of vitamins $\mathrm{A}$ and $\mathrm{C}$ with seeds that are rich in omega-3, omega- 6 polyunsaturated fatty acids and especially dietary fiber, riboflavin, as well as in proteins, and mineral salts, calcium, etc. Guava is normally consumed fresh as a desert fruit can be processed into juice, nectar, pulp, jam, jelly, slices in syrup, fruit bar or dehydrated products, as well as being used as an additive to other fruit juices or pulps (Leite et al., 2006). Excellent salad, pudding, jam, jelly, cheese, canned fruit, RTS, nectar, squash, ice cream and toffees are made from guava (Jain and Asati, 2004). However, guava is highly perishable and cannot be stored for longer period. Moreover considerable proportion of the produce is lost during post-harvest linkage (Ahire, 1989). It is, therefore, imperative to develop suitable technology for preservation and processing of such surplus produce. With the changing consumer attitudes, demands and emergence of new market products, it has become imperative for producers to develop products, which have nutritional as well as health benefits. In this context, guava has excellent digestive and nutritive value, pleasant flavor, high palatability and availability in abundance at moderate price there has been greater increase in the production rate of these fruits over the years, and this may be due to their increased consumption pattern in the tropics (FAO, 1983). Fruit leathers are dehydrated fruit based products. Fruit leathers are made by pouring pureed fruit onto a flat surface for drying. Due to its novel and attractive structure, and for being products that do not require refrigeration, they constitute a practical way to incorporate fruit solids, especially for children and adolescents. Fruit leathers allow leftover ripe fruits to be preserved. Therefore Preparation of guava leather from two kinds of fully ripened guava fruits one is of white flesh of Sardar variety and another of pink flesh Lalith fruits considered to study effect of storage period on physio chemical properties of guava leather.

\section{Materials and Methods}

\section{Raw materials}

Well-matured, healthy, uniform sized over ripen fruits of local Lalith of pink and Sardar or Lucknow-49 of white flesh cultivars were collected from the Department of Horticulture and progressive farmers of the Rahuri, Nasik, Yeola Tahashils.

\section{Ingredients}

Citric acid, salt, sugar and hydrogenated fat were obtained from market and used as ingredients for preparation of guava leather. 


\section{Chemicals}

Most of the chemicals used in this investigation were of analytical grade, obtained from M/s. British Drug House Mumbai, M/s. Sarabhai M. Chemicals, M/s. Baroda, S.D. Fine Chemical Ltd., Mumbai and E. Merck (India), Mumbai.

\section{Preparation of guava leathers}

The guava fruit pulp was used for the preparation of fruit leather. In the pulp sugar, salt as per the formula added, mixed well and then smeared on the aluminium or stainless steel trays. Spread the pulp in thin layer $(0.5$ to $1.0 \mathrm{~cm}$ thick). Then the pulp was dried in hot air oven at $50{ }^{\circ} \mathrm{C}$ for $8-10 \mathrm{hrs}$. After that dried pulp sheets were cut into desired size and again dried for 8-10 hrs. After drying three layers of sheets were kept together and pressed properly to form one sheet. Then desired size $(3 \times 4 \mathrm{~cm})$ cutting was done and dried under fan for 2-3 hrs and then wrapped into a metalized polyester wrapper and then kept in plastic bag for storage study.

\section{Standardization of ingredient levels for guava leather}

Preliminary experiments were conducted to select the optimum level of each ingredient like sugar, salt, citric acid. The optimum levels of ingredients were finalized by sensory evaluation of guava leather by a panel of minimum ten semi-trained judges using 9 points Hedonic scale (Amerine et al., 1965).

\section{Packaging}

The prepared leathers were packed in a butter paper stored at both ambient $\left(25+2^{\circ} \mathrm{C}\right)$ and refrigerated $\left(7+2^{\circ} \mathrm{C}\right)$ temperature safely in laboratory at the middle compartment of the refrigerator for 3 months storage study. Chemical analysis, organoleptic evaluation and microbial analysis of stored guava leathers were carried out at an interval of $0,30,60,90$ day's storage period.

\section{Physicochemical analysis}

The over ripen guava fruit pulp was analyzed for the moisture, TSS, titrable acidity, reducing sugars, total sugars, and vitamin $\mathrm{C}$ using standard methods of AOAC (2005).

\section{Statistical analysis}

Results and experiments were planned and carried out using Factorial Completely Randomized Design (FCRD) using three to ten replications according to methods of the procedure given by Panse and Sukhatme (1967).

\section{Results and Discussion}

\section{Physio-chemical characteristics of Sardar guava fruit and pulp}

The physio-chemical composition of fruit plays a very important role in processing technology of guava as well as final quality of the product. The Physio-chemical composition of Sardar cultivar of guava is presented in Table 2. The over ripened fruits were round, yellowish in color. The average weight of fruit was $139 \mathrm{~g} /$ fruit. The average values for recovery of pulp and processing losses were 92.60 and 7.40 per cent, respectively.

\section{Physio-chemical characteristics of Lalith guava fruit and its pulp}

Lalith fruits were attractive, saffron yellow with occasional red blush and medium sized with firm pink colored flesh. It has good blend of sugar and acid and suitable for both processing and table purpose. Its yield was more than 24 per cent than the Allahabad Safeda variety (Yadav, 2007). The over ripen 
fruits of Lalith were round, yellowish in color. The average weight of fruit was $126 \mathrm{~g} /$ fruit. The average values for recovery of pulp and processing losses were 91.0 and 9.0 per cent, respectively.

\section{Changes in chemical composition of guava leathers during storage}

Guava leather prepared from selected treatments from both varieties was kept for storage study at ambient $\left(27+2^{\circ} \mathrm{C}\right)$ and refrigerator $\left(7+2^{\circ} \mathrm{C}\right)$ temperatures. The storage study results of guava leathers were presented in Tables 4 to 7 .

\section{Chemical properties of guava leathers}

Chemical properties of guava leathers are mentioned in table 3. There was slight variation in chemical properties which might be due to change in variety. Pink flesh guava leather has low amount of ascorbic content when compared to the sardar guava leather

\section{Moisture (\%)}

The moisture content was reduced from 15.85 to 14.67 per cent at ambient temperature and 15.85 to 15.07 per cent at refrigerated temperature when stored for three months. Mean values of moisture content were reduced with the advancement of increase in storage period as shown in Tables 4 to 7 . The moisture content in guava leathers stored at ambient condition was reduced at higher rate than in the refrigerated condition, which might be due to the higher temperature of the ambient condition than the refrigerated temperature, responsible for removal of moisture from guava leather samples., $\mathrm{V}_{2} \mathrm{~T}_{1}$ treatment was found more suitable to maintain the moisture level at higher value in guava leathers than the other treatments. In consistent with these results, the decrease in moisture content during storage was reported in mango leather
(Rao and Roy, 1980a), sweet potato leather (Collins and Hutsell, 1987), dried fig (Chandeshwar et al., 2004), mango leather (Gill et al., 2004), fig leather (Kotlawar, 2008), tamarind leather (Kharche, 2012), the results obtained in present investigation are parallel with literature

\section{Total soluble solids TSS $\left({ }^{0}\right.$ Brix $)$}

Due to decrease in moisture content there was increase in TSS content of guava leathers from 75.95 to 77.20 per cent at ambient temperature, 75.95 to 76.81 per cent at refrigerated temperature. With the advancement of increase in storage period mean values of TSS content were increased as shown in Tables 4 to 7 . It was observed that there was gradual increase in TSS content at ambient condition than at refrigerated condition. Sample $\mathrm{V}_{1} \mathrm{~T}_{1}$ stored at ambient temperature had the highest content of total soluble solids.

The increase in TSS content during storage period was reported in fig (Mali, 1997; Palve, 2002; Gawade and Waskar, 2003 and Chandeshwar et al., 2004) dried fig leather (Kotlawar, 2008), changes in guava leather packed in different packaging materials and stored at different storage conditions (Muhammad, 2014) and (Chavan, 2015) mixed toffee from guava and strawberry also increased TSS level due to reduction in moisture content. The results obtained in present investigation showed similar trend as shown in literature.

\section{Titrable acidity (\%)}

The titrable acidity of guava leathers increased in all samples. Mean values of titrable acidity are increased from 0.476 to 0.518 per cent at ambient temperature and from 0.476 to 0.506 per cent at refrigerated temperature during storage period of 3 months. Acidity was at 
higher level in treatment $\mathrm{V}_{1} \mathrm{~T}_{1}$ and $\mathrm{V}_{2} \mathrm{~T}_{1}$ than in $V_{1} T_{2}$ and $V_{2} T_{2}$, it may be due to the addition of citric acid in treatments $\mathrm{V}_{1} \mathrm{~T}_{1}$ and $\mathrm{V}_{2} \mathrm{~T}_{1}$. Whereas, in other two treatments citric acid was not added. The changes in titrable acidity of guava leathers are presented in Tables 4 to 7 . Changes in titrable acidity statistically were non-significant up to 30 days but after that there was significant change. The increase in titrable acid content was reported in mango leather (Rao and Roy, 1980), fig leather (kotlawar, 2008), high protein tamarind leather (Kharche, 2012) and changes in guava leather packed in different packaging materials, at different storage conditions (Muhammad, 2014). The results obtained in present investigation are parallel to earlier reports

\section{Reducing sugars (\%)}

A significant variation in reducing sugar content of guava leathers was observed during storage. Due to more inversion of added sugars in guava leather samples during storage. The content of reducing sugars in guava leathers increased with progress of storage period.

Fig.1 Flow sheet for preparation of guava leather

Selection of guava fruits (over ripen)

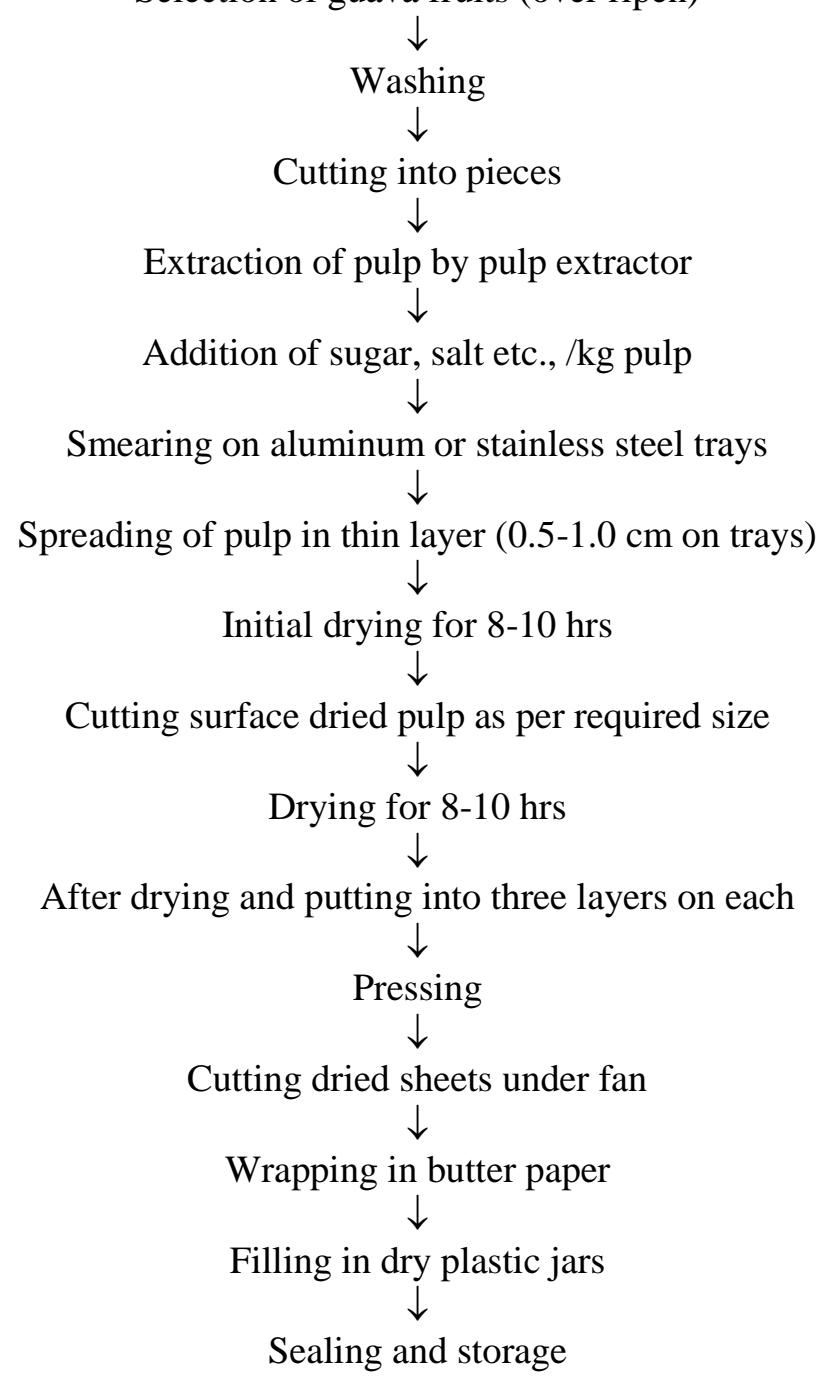


Table.1 Treatment details for experimentation

\begin{tabular}{|c|c|c|c|c|}
\hline Treatments & Pulp (\%) & Sugar $(\%)$ & Salt (\%) & Citric acid (\%) \\
\hline $\mathrm{T}_{1}$ & 100 & 500 & 5 & 2 \\
\hline $\mathrm{T}_{2}$ & 100 & 750 & 5 & 2 \\
\hline $\mathrm{T}_{3}$ & 100 & 1000 & 5 & 2 \\
\hline $\mathrm{T}_{4}$ & 100 & 750 & 5 & 4 \\
\hline $\mathrm{T}_{5}$ & 100 & 750 & - & - \\
\hline $\mathrm{T}_{6}$ & 100 & 750 & 5 & - \\
\hline $\mathrm{T}_{7}$ & 100 & 750 & - & 4 \\
\hline
\end{tabular}

Table.2 Physio-chemical characteristics of Sardar, Lalith guava fruits

\begin{tabular}{|c|c|c|c|}
\hline S. No. & Parameters & $\begin{array}{c}\text { Sardar (white } \\
\text { flesh) }\end{array}$ & Lalith (Pink flesh) \\
\hline A. & \multicolumn{2}{|c|}{ Physical parameters of fruits } & \\
\hline 1. & Shape & Round & Round \\
\hline 2. & Color & Yellow & Saffron yellow \\
\hline 3. & Average length $(\mathrm{cm})$ & 6.20 & 4.10 \\
\hline 4. & Average fruit weight (g) & 139.0 & 126 \\
\hline 5. & Diameter $(\mathrm{cm})$ & 6.20 & 6.2 \\
\hline 6. & Per cent of pulp recovery $(\%)$ & 92.60 & 91.0 \\
\hline 7. & Waste material/Seed content losses (\%) & 7.40 & 9.0 \\
\hline B. & \multicolumn{2}{|c|}{ Chemical constituents of Pulp } & \\
\hline 1. & TSS ( ${ }^{\circ}$ Brix $)$ & 9.20 & 9.10 \\
\hline 2. & Acidity (\%) & 0.450 & 0.380 \\
\hline 3. & Total sugars $(\%)$ & 7.70 & 5.10 \\
\hline 4. & Reducing sugars (\%) & 5.30 & 7.40 \\
\hline 5. & Vitamin C (mg/100 g) & 210 & 130 \\
\hline 6. & Moisture (\%) & 82.56 & 83.60 \\
\hline
\end{tabular}

Table.3 Chemical properties of fresh guava leathers ${ }^{\mathrm{a}}$

\begin{tabular}{|c|c|c|c|c|c|c|}
\hline Treatments & $\begin{array}{c}\text { Moisture } \\
(\%)\end{array}$ & $\begin{array}{c}\text { TSS } \\
\left({ }^{0} \text { Brix }\right)\end{array}$ & $\begin{array}{c}\text { Titrable } \\
\text { acidity } \\
(\%)\end{array}$ & $\begin{array}{c}\text { Reducing } \\
\text { sugars } \\
(\%)\end{array}$ & $\begin{array}{c}\text { Total } \\
\text { sugars } \\
(\%)\end{array}$ & $\begin{array}{c}\text { Ascorbic } \\
\text { acid } \\
(\mathrm{mg} / 100 \mathrm{~g})\end{array}$ \\
\hline $\mathrm{V}_{1} \mathrm{~T}_{1}$ & 15.29 & 76.10 & 0.541 & 14.32 & 68.72 & 125.28 \\
\hline$V_{1} T_{2}$ & 15.12 & 76.00 & 0.462 & 14.12 & 68.23 & 127.30 \\
\hline $\mathrm{V}_{2} \mathrm{~T}_{1}$ & 16.75 & 75.85 & 0.490 & 14.19 & 68.47 & 71.81 \\
\hline $\mathrm{V}_{2} \mathrm{~T}_{2}$ & 16.27 & 75.85 & 0.412 & 12.92 & 68.28 & 73.34 \\
\hline SEm + & 0.024 & 0.036 & 0.0011 & 0.014 & 0.010 & 0.127 \\
\hline CD at $5 \%$ & 0.073 & NS & NS & 0.045 & 0.032 & NS \\
\hline
\end{tabular}

$\mathrm{V}_{1:}$ Sardar guava variety (white flesh), $\mathrm{V}_{2}$ : Lalith guava variety (Pink flesh).

$\mathrm{T}_{1}: 750 \mathrm{~g}$ sugar $+5 \mathrm{~g}$ salt $+2 \mathrm{~g}$ citric acid per kg guava pulp,

$\mathrm{T}_{2}: 750 \mathrm{~g}$ sugar per kg guava pulp. 
Table.4 Effect of storage period on Physio-chemical composition of fresh guava leathers at 0 days storage

\begin{tabular}{|c|c|c|c|c|c|c|}
\hline Treatments & $\begin{array}{c}\text { Moisture } \\
(\%)\end{array}$ & $\begin{array}{l}\text { TSS } \\
(\%)\end{array}$ & $\begin{array}{c}\text { Acidity } \\
(\%)\end{array}$ & $\begin{array}{c}\text { Reducing } \\
\text { sugars (\%) }\end{array}$ & $\begin{array}{c}\text { Total sugars } \\
(\%)\end{array}$ & $\begin{array}{l}\text { Ascorbic acid } \\
\text { (mg/100g) }\end{array}$ \\
\hline \multicolumn{7}{|l|}{ Variety } \\
\hline$\overline{V_{1}}$ & 15.20 & 76.05 & 0.501 & 14.22 & 68.47 & 126.29 \\
\hline$\overline{V_{2}}$ & 16.50 & 75.85 & 0.451 & 13.55 & 68.37 & 72.58 \\
\hline $\operatorname{SEm}( \pm)$ & 0.017 & 0.026 & 0.0007 & 0.010 & 0.007 & 0.090 \\
\hline CD@ $9 \%$ & 0.052 & 0.080 & 0.0024 & 0.032 & 0.022 & 0.278 \\
\hline \multicolumn{7}{|l|}{ Treatments } \\
\hline$\overline{T_{1}}$ & 16.02 & 75.97 & 0.516 & 14.26 & 68.60 & 98.54 \\
\hline$\overline{T_{2}}$ & 15.69 & 75.92 & 0.437 & 13.52 & 68.25 & 100.32 \\
\hline $\operatorname{SEm}( \pm)$ & 0.017 & 0.026 & 0.0007 & 0.010 & 0.007 & 0.090 \\
\hline CD@ $9 \%$ & 0.052 & NS & 0.0024 & 0.032 & 0.022 & 0.278 \\
\hline \multicolumn{7}{|c|}{ Two factor interaction } \\
\hline$\overline{V_{1} T_{1}}$ & 15.29 & 76.10 & 0.541 & 14.32 & 68.72 & 125.28 \\
\hline$\overline{V_{1} T_{2}}$ & 15.12 & 76.00 & 0.462 & 14.12 & 68.23 & 127.30 \\
\hline $\mathrm{V}_{2} \mathrm{~T}_{1}$ & 16.75 & 75.85 & 0.490 & 14.19 & 68.47 & 71.81 \\
\hline $\mathrm{V}_{2} \mathrm{~T}_{2}$ & 16.27 & 75.85 & 0.412 & 12.92 & 68.28 & 73.34 \\
\hline $\operatorname{SEm}( \pm)$ & 0.024 & 0.036 & 0.0011 & 0.014 & 0.010 & 0.127 \\
\hline CD@ $9 \%$ & 0.073 & NS & NS & 0.045 & 0.032 & NS \\
\hline
\end{tabular}

A=Ambient $\left(25 \pm 2{ }^{\circ} \mathrm{C}\right), \mathrm{R}=$ Refrigerated $\left(5 \pm 2{ }^{0} \mathrm{C}\right)$

$\mathrm{V}_{1:}$ Sardar guava variety (white flesh), $\mathrm{V}_{2}$ : Lalith guava variety (Pink flesh).

$\mathrm{T}_{1}: 750 \mathrm{~g}$ sugar $+5 \mathrm{~g}$ salt $+2 \mathrm{~g}$ citric acid per kg guava pulp, $\mathrm{T}_{2}: 750 \mathrm{~g}$ sugar per kg guava pulp. 
Table.5 Effect of storage period on Physio-chemical composition of guava leather at 30 days storage

\begin{tabular}{|c|c|c|c|c|c|c|c|c|c|c|c|c|}
\hline \multirow[t]{2}{*}{ Treatments } & \multicolumn{2}{|c|}{$\begin{array}{l}\text { Moisture } \\
(\%)\end{array}$} & \multicolumn{2}{|c|}{$\begin{array}{l}\text { TSS } \\
(\%)\end{array}$} & \multicolumn{2}{|c|}{$\begin{array}{l}\text { Acidity } \\
(\%)\end{array}$} & \multicolumn{2}{|c|}{$\begin{array}{c}\text { Reducing sugars } \\
(\%)\end{array}$} & \multicolumn{2}{|c|}{$\begin{array}{l}\text { Total sugars } \\
(\%)\end{array}$} & \multicolumn{2}{|c|}{$\begin{array}{l}\text { Ascorbic acid } \\
(\mathrm{mg} / 100 \mathrm{~g})\end{array}$} \\
\hline & A & $\mathrm{R}$ & A & $\mathrm{R}$ & A & $\mathrm{R}$ & A & $\mathrm{R}$ & A & $\mathrm{R}$ & A & $\mathrm{R}$ \\
\hline \multicolumn{13}{|l|}{ Variety } \\
\hline$\overline{V_{1}}$ & 15.41 & 15.04 & 76.75 & 76.29 & 0.519 & 0.512 & 15.30 & 14.693 & 68.73 & 68.61 & 114.88 & 121.03 \\
\hline $\mathbf{V}_{2}$ & 16.10 & 16.26 & 76.71 & 76.21 & 0.481 & 0.458 & 14.90 & 13.62 & 68.65 & 68.52 & 64.76 & 68.52 \\
\hline $\operatorname{SEm}( \pm)$ & 0.010 & 0.019 & 0.019 & 0.013 & 0.0009 & 0.0014 & 0.014 & 0.009 & 0.012 & 0.014 & 0.086 & 0.013 \\
\hline CD@ $9 \%$ & 0.032 & 0.059 & NS & 0.042 & 0.0030 & 0.0044 & 0.043 & 0.028 & 0.038 & 0.043 & 0.266 & 0.040 \\
\hline \multicolumn{13}{|l|}{ Treatments } \\
\hline $\mathrm{T}_{1}$ & 15.71 & 15.84 & 76.74 & 76.39 & 0.551 & 0.526 & 15.28 & 14.55 & 68.88 & 68.74 & 89.14 & 94.01 \\
\hline$\overline{T_{2}}$ & 15.80 & 15.46 & 76.72 & 76.11 & 0.449 & 0.444 & 14.92 & 13.76 & 68.52 & 68.39 & 90.51 & 95.55 \\
\hline $\operatorname{SEm}( \pm)$ & 0.010 & 0.019 & 0.019 & 0.013 & 0.0009 & 0.0014 & 0.014 & 0.009 & 0.012 & 0.014 & 0.086 & 0.013 \\
\hline CD@ $9 \%$ & 0.032 & 0.059 & NS & 0.042 & 0.0030 & 0.0044 & 0.043 & 0.028 & 0.038 & 0.043 & 0.266 & 0.040 \\
\hline \multicolumn{13}{|c|}{ Two factor interaction } \\
\hline$\overline{V_{1} T_{1}}$ & 15.03 & 15.15 & 76.79 & 76.40 & 0.562 & 0.552 & 15.52 & 14.83 & 69.01 & 68.86 & 114.41 & 120.41 \\
\hline $\mathrm{V}_{1} \mathrm{~T}_{2}$ & 15.80 & 14.92 & 76.72 & 76.17 & 0.476 & 0.472 & 15.08 & 14.55 & 68.46 & 68.36 & 115.36 & 121.65 \\
\hline $\mathrm{V}_{2} \mathrm{~T}_{1}$ & 16.40 & 16.52 & 76.70 & 76.39 & 0.540 & 0.500 & 15.04 & 14.27 & 68.75 & 68.62 & 63.86 & 67.60 \\
\hline $\mathrm{V}_{2} \mathrm{~T}_{2}$ & 15.80 & 16.01 & 76.72 & 76.04 & 0.422 & 0.4166 & 14.76 & 12.97 & 68.57 & 68.42 & 65.66 & 69.44 \\
\hline $\operatorname{SEm}( \pm)$ & 0.015 & 0.027 & 0.026 & 0.019 & 0.0014 & 0.0020 & 0.019 & 0.013 & 0.018 & 0.020 & 0.122 & 0.018 \\
\hline CD@ $9 \%$ & 0.045 & 0.083 & NS & 0.060 & 0.0043 & NS & 0.061 & 0.040 & 0.054 & 0.062 & 0.377 & 0.056 \\
\hline
\end{tabular}

$\mathrm{A}=$ Ambient $\left(25 \pm 2{ }^{\circ} \mathrm{C}\right), \mathrm{R}=$ Refrigerated $\left(5 \pm 2{ }^{\circ} \mathrm{C}\right)$

$\mathrm{V}_{1:}$ Sardar guava variety (white flesh), $\mathrm{V}_{2}$ : Lalith guava variety (Pink flesh).

$\mathrm{T}_{1}: 750 \mathrm{~g}$ sugar $+5 \mathrm{~g}$ salt $+2 \mathrm{~g}$ citric acid per kg guava pulp, $\mathrm{T}_{2}: 750 \mathrm{~g}$ sugar per $\mathrm{kg}$ guava pulp. 
Table.6 Effect of storage period on Physio-chemical composition of guava leather at 60 days storage

\begin{tabular}{|c|c|c|c|c|c|c|c|c|c|c|c|c|}
\hline \multirow[t]{2}{*}{ Treatments } & \multicolumn{2}{|c|}{$\begin{array}{l}\text { Moisture } \\
(\%)\end{array}$} & \multicolumn{2}{|c|}{$\begin{array}{l}\text { TSS } \\
(\%)\end{array}$} & \multicolumn{2}{|c|}{$\begin{array}{l}\text { Acidity } \\
(\%)\end{array}$} & \multicolumn{2}{|c|}{$\begin{array}{l}\text { Reducing } \\
\text { sugars }(\%)\end{array}$} & \multicolumn{2}{|c|}{$\begin{array}{c}\text { Total sugars } \\
(\%)\end{array}$} & \multicolumn{2}{|c|}{$\begin{array}{l}\text { Ascorbic acid } \\
(\mathrm{mg} / 100 \mathrm{~g})\end{array}$} \\
\hline & A & $\mathrm{R}$ & A & $\mathrm{R}$ & A & $\mathrm{R}$ & A & $\mathrm{R}$ & A & $\mathrm{R}$ & A & $\mathrm{R}$ \\
\hline$\overline{V_{1}}$ & 14.46 & 14.84 & 77.04 & 76.71 & 0.528 & 0.522 & 16.78 & 16.12 & 68.86 & 68.66 & 105.33 & 116.07 \\
\hline $\mathbf{V}_{2}$ & 15.84 & 16.06 & 76.96 & 76.45 & 0.480 & 0.470 & 14.98 & 14.87 & 68.79 & 68.59 & 56.41 & 62.41 \\
\hline CD@5\% & 0.128 & 0.041 & 0.044 & 0.034 & 0.0044 & 0.0034 & 0.030 & 0.030 & 0.059 & 0.023 & 0.339 & 0.033 \\
\hline \multicolumn{13}{|l|}{ Treatments } \\
\hline $\mathrm{T}_{1}$ & 15.35 & 15.60 & 77.04 & 76.66 & 0.546 & 0.536 & 16.25 & 15.48 & 68.95 & 68.78 & 79.91 & 89.28 \\
\hline $\mathbf{T}_{2}$ & 14.96 & 15.29 & 76.96 & 76.50 & 0.463 & 0.456 & 15.51 & 15.52 & 68.71 & 68.46 & 81.83 & 89.20 \\
\hline$\overline{V_{1} T_{1}}$ & 14.57 & 14.92 & 77.08 & 76.81 & 0.577 & 0.562 & 16.86 & 16.15 & 69.05 & 68.92 & 104.63 & 116.07 \\
\hline$\overline{V_{1} T_{2}}$ & 14.36 & 14.75 & 77.00 & 76.61 & 0.480 & 0.482 & 16.70 & 16.10 & 68.67 & 68.41 & 106.03 & 116.06 \\
\hline $\mathrm{V}_{2} \mathrm{~T}_{1}$ & 16.13 & 16.28 & 77.01 & 76.51 & 0.516 & 0.510 & 15.64 & 14.80 & 68.84 & 68.65 & 55.18 & 62.48 \\
\hline $\mathrm{V}_{2} \mathrm{~T}_{2}$ & 15.56 & 15.84 & 76.92 & 76.39 & 0.4453 & 0.430 & 14.32 & 14.94 & 68.74 & 68.52 & 57.63 & 62.33 \\
\hline $\operatorname{SEm}( \pm)$ & 0.059 & 0.019 & 0.020 & 0.015 & 0.0020 & 0.0015 & 0.014 & 0.013 & 0.027 & 0.010 & 0.155 & 0.015 \\
\hline CD@ $9 \%$ & 0.181 & 0.058 & NS & 0.048 & 0.0063 & NS & 0.043 & 0.042 & 0.083 & 0.033 & 0.480 & 0.047 \\
\hline
\end{tabular}


Table.7 Effect of storage period on Physio-chemical composition of guava leather at 90 days storage

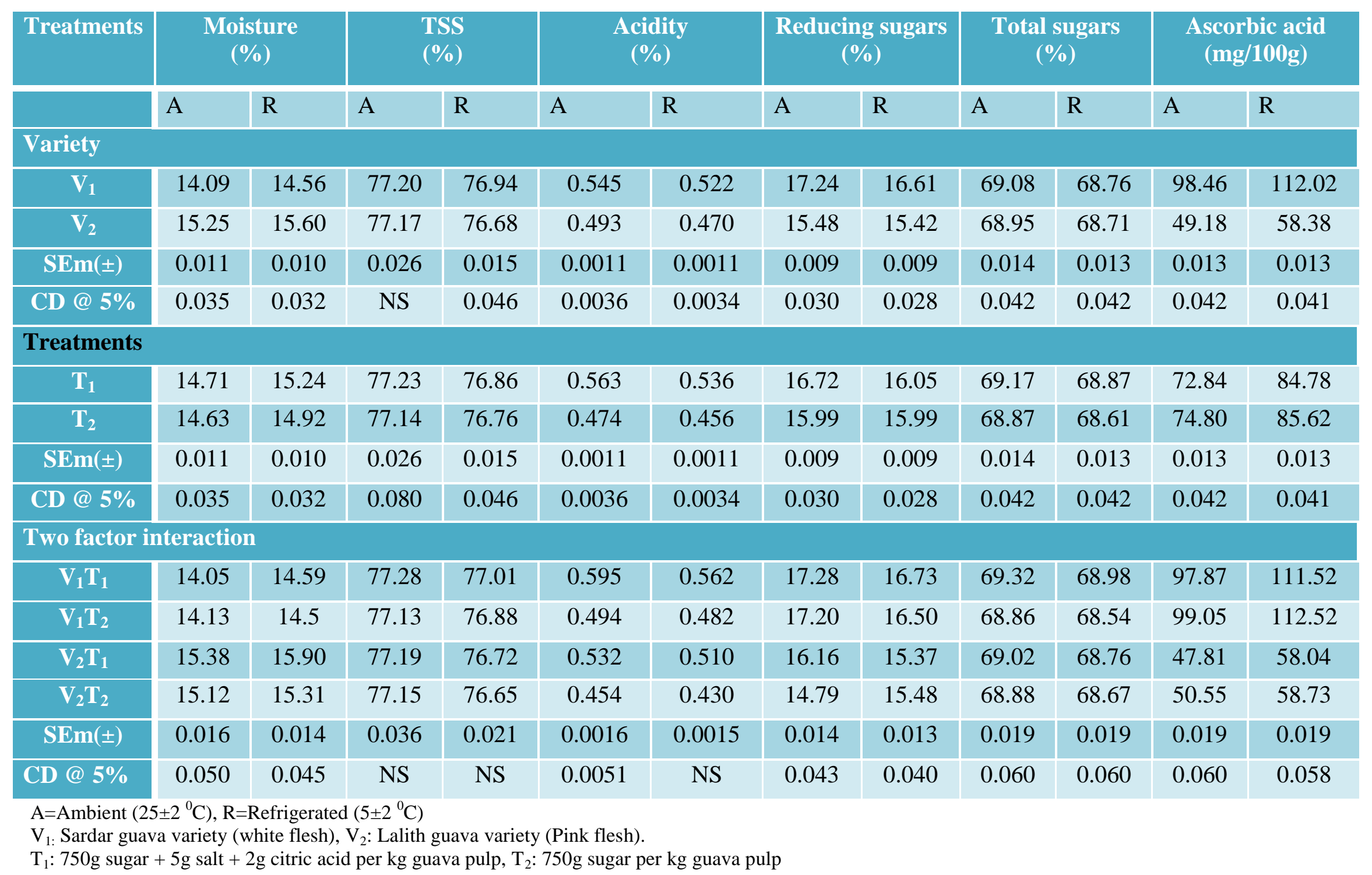


The mean values of reducing sugar content increased from 13.88 to 16.35 per cent at ambient temperature and from 13.88 to 16.02 per cent at refrigerated temperature during 3 months storage. The increase in reducing sugars at ambient temperature was more than at refrigerated temperature.

The changes in reducing sugar content of guava leather samples are presented in Tables 4 to 7 . These results indicated that the increase in storage temperature is the responsible factor for increase in reducing sugars while storing the guava leathers at two different storage temperature conditions.

Similar results of increase in reducing sugars were also reported in mango leather sugars during were reported in mango leather (Rao and Roy, 1980), mango fruit bars (Mir and Nirankarnath, 1993), jackfruit bar (Krishnaveni et al., 1999), papaya-guava fruit bar (Vennilla et al., 2004), fig leather (kotlawar, 2008), mixed fruit toffee from fig and guava fruits (Chavan, 2012) and Muhammad (2014) also reported that when guava leather packed in different packaging materials and stored at different storage conditions also increased reducing sugar levels.

\section{Total sugars (\%)}

There was gradual increase in total sugar content of guava leathers with increase in storage time. This may be due to higher storage temperature at ambient temperature and reduction in moisture content from guava leather samples. The total sugars of guava leather samples ranged from 68.42 to 69.02 per cent at ambient temperature and from 68.42 to 68.73 per cent at refrigerated temperature during 3 months storage. The results on changes in total sugar content of guava leathers during storage are presented in Tables 4 to 7 .
Similar results were reported that total sugar content also increased in sweet potato leather (Collins and Hutsell, 1987), jack fruit leather (Che Man and Taufik, 1995), fig and other fruit products (Doreyappa Gowda et al., 1995), mango fruit bar with respect to storage temperature (Doreyappa Gowda et al., 1995), guava-papaya fruit bar (Vennilla et al., 2004), changes in guava leather packed in different packaging materials stored at different temperature conditions (Muhammad, 2014) and mixed toffee from guava and strawberry (Chavan, 2015). The results obtained in the present investigation are comparable to those reported in the literature.

\section{Ascorbic acid (mg/100 g)}

Significant difference in the ascorbic acid content was observed in guava leather samples during storage with two different temperature conditions with respect to storage period of 3 months. The ascorbic acid content of guava leather samples gradually decreased with the advancement of storage period. It decreased from 99.36 to $73.79 \mathrm{mg} / 100 \mathrm{~g}$ at ambient temperature and from 99.36 to 60.16 $\mathrm{mg} / 100 \mathrm{~g}$ at refrigerated temperature.

It was observed that ascorbic acid content of guava leather samples was higher level when stored at refrigerated temperature than at ambient temperature. The ascorbic acid content of guava leather samples were successfully maintained when stored at refrigerated temperature. The decrease in the ascorbic acid content at ambient condition might be due to oxidation of ascorbic acid at high storage temperature. The result on changes in ascorbic acid content of guava leathers during storage are presented in Tables 4 to 7 .

The decrease in ascorbic acid content during storage was also reported in dried figs (Pawar et al., 1992), mango fruit bar (Mir and 
Nirankarnath, 1993 and Doreyappa Gowda et al., 1995), dried figs (Thonta and Patil, 1998), guava-papaya fruit bar (Vennilla et al., 2004), fig leather (Kotlawar, 2008), storage of guava leather packed in different packaging materials, stored at different storage conditions (Muhammad, 2014) and mixed toffee from guava and strawberry (Chavan, 2015).

From the results of this research it was concluded that in physicochemical analysis, guava leather prepared with treatment $T_{1}$ showed better organoleptic properties as well as good storage stability at both storage (ambient and refrigerated) conditions up to 3 months storage period

\section{Recommendations}

Study should be carried out in the effect of different packaging materials

Study the effect of different drying methods

Further studies on preparation of guava leather and preservation using other preservatives

Preparation of guava leather on pilot scale needed to undertake for its better utilization.

\section{References}

A.O.A.C. 2005. Official Methods of Analysis. 18th Edn. Association of Official Analytical Chemists, Virginia, USA. pp. 321.

Amerine, M.A., Pangborn, R.M. and Osler, E.B. 1965. Principles of sensory evaluation of food. Academic press, New York. pp. 350-480.

Balasubramanian, S. 2007. Studies on textural properties of selected pulps and its retexturised fruit bars. Beverage Food World. 34(2): 67-69.
Bhagirathi, B., Rao, V. and Shrihari, K. 1993. Microbiological studies on the production of dehydrated convenience foods. J. Food Sci. Technol. 30(6): 403407.

Bijay Kumar, 2011. Indian Horticulture Database- 2010. National Horticulture Board 124-127

Chavan U.D., Pawar, U.B. Pawar, G.H. March 2015. Studies on preparation of mixed toffee from guava and strawberry. J. Food Sci. Technol., DOI 10.1007/s13197-015-1786-3.

Chavan U.D., Kohinkar S.N.2012. Osmotic dehydration process for preservation of fruits and vegetables. 1(2): 202.

Che Man, Y.B. and Taufik.1995. Development and stability of jack fruit leather. Tropical; Sci. 35(3): 245-250.

Collins, J.L. and Hutsell, L.W. 1987. Physical, Chemical, Sensory and Microbiology attributes of sweet potato leather. J. Food Sci., 52.

DAC (Department of Agriculture and cooperation). 2007. Ministry of Agriculture, Govt. of

Doreyappa Gowda, I.N., Amba Dan and Ramanjaneya, K.H. 1995. Studies on mango fruit bar preparation. Indian Food Packer. March-April 17.

FAO (1983). Production yearbook, Rome.

Gawade, M.H. and Waskar, D.P. 2003. Studies on processing and storage of fig fruits. J. Maharashtra agric. Univ. 28(2): 148-150.

Gill, B.S., Sodhi, N.S., Singh, C.N., Singh, M. and Singh, D. 2004. Effects of Brix, sodium alginate and drying temperature on color texture and sensory properties of 'Dashehari' mango leather, J. Food Sci. Technol. 41(4): 373-378.

Harrigan*, W.F. and Mccance, M.E. 1966. Laboratory Methods in Microbiology. Academic press. London. pp. 14-16.

Harvey, T.C. Jr. and Cavaletto, G. 1978. Dehydration and storage stability of 
Papaya leather. J. Food Sci. 43: 17231725.

Jagtiani, J., Chan, H.T. and Sakai, W.S. 1998. Guava in tropical fruit processing, Academic Press, New York. pp. 9-44

Jain, P.K. and Asati, V.K. 2004. Evaluation of guava cultivars for pulp preparation. J.Food Sci.Technol. 41(6):684-686.

Joshi, A. 2009. Studies on processing and value addition of sweet tamarind (variety- Ajanta) M.Sc. (Agri.) Thesis. M.A.U Parbhani.

Kharche, K.M. 2012. Studies on preparation of high protein leather from tamarind. M.Sc.

Kohinkar S.N., Chavan U.D., Pawar U.D., and Amarowicz. R. 2014. Studies on preparation of mixed fruit toffee from fig and guava fruits. J. Food Sci. Technol. 51(9), 2204-2209.

Kotlawar, N.G. 2008. Investigations on preparation and shelf life of fig leather. M.Sc. Thesis., M.P.K.V., Rahuri.

Krishnaveni, A., Manimegalai, G., Venilla, P. and Saravanakumar, R. 1999. Storage stability of jackfruit bar in different packaging materials. Indian Food packer. 53(6): 67-71.

Lane, J.H. and Eynon, L. 1923. Determination of sugars by Fehling solution with methylene blue as internal indicator. $J$. Soc. Chem. India.42:32-34.

Le Maguer*, M. 1988. Osmotic dehydration, Review and future directions. In Proc. International symposium on progress in food preservation and processes. Brussels, Belgium, 1: 283-309.

Leite, K.M.S.C., Tadiotti, A.C., Baldochi, D. and Oliveria, O.M.M.F. (2006). Partial purification, heat stability and kinetic characterization of the pectin methylesterase from Brazilian guava Plauma cultivars. Food Chemistry. 94, 565-572.
Mir, M.A, and Nirankarnath, M. 1993. Storage changes in fortified mango bars. J. Food Sci. Technol. 30(4): 279-282.

Misra, K. and Sheshadri, T.R. 1968. Chemical components of fruits of guava. Phytochemistry. 7(4): 641.

Mitra, K., Ghosh, S.K. and Dhua, R.S. 1984. Ascorbic acid content in different varieties of guava grown in West Bengal. Sci. Cult. 50: 235.

Muhammad NaeemSafdar. 2014. Quality of guava leather as influenced by storage period and

Panse, V.G. and Sukhatme, P.V. 1967. Statistical Methods for Agril. Workers, Indian Council of Agril Research, New Delhi. pp. 70-72.

Pawar, S.G., Kulkarni, D.N., Shere, D.M., Kulkarni, K.d., Paril, V.K. 1992. Effect of pretreatments on chemical composition and drying rates of solar dried figs.

Ranganna*, S. 1986. Handbook of Analysis and Quality Control for Fruit and vegetable Products. McGraw-Hill Tata Pub. Co. Ltd., New Delhi. pp. 7-12 and 109.

Rao, M.A. 1977. Energy consumption in refrigerated canned and frozen peas. $J$. Food Proc. Engg. 1: 149-169.

Rao, S.V. and Roy S.K. 1980a. Studies on dehydration of mango pulp. I Standardization of making mango sheets/ leather. Indian Food Packer. 34 (3): 64-71.

Rao, S.V. and Roy S.K. 1980b. Studies on dehydration of mango pulp. II Storage studies of mango sheets/leather. Indian Food Packer.34 (3): 72-79.

Rathore, D.S. 1976. Effects of season on growth and chemical composition of guava fruits. J. Hort. Sci. 51 (1): 41.

Rozina Naz., 2012. Physical properties, sensory attributes and consumer preference of fruit 
Singh, M. 1988. Performance of some cultivars of guava with special reference to their commercial significance in the central gangetic plains. Punjab Hort. J. 28 (1 and 2): 50.

Somogyi, L. P., Barret, D.M. and Hui, Y.H. 1996. Major processed product. 2 US: Technomic Publishing Co. Inc.

Thonta, G.T. and Patil, V.K. 1988. Studies on drying of fig fruits Indian Food Packer.42 (4): 94-99.
Vennilla, P.2004. Studies on storage behavior of guava-papaya fruit bar. Beverage Food world. 31(2): 63-66.

Verma, A.R. and Shrivastava, J.C. 1965. Pectin in guava during growth and maturity. Indian J. Hort. 22 (1 and 2): 318.

Yadav*, P.K. 2007. Handbook of Fruit Production Technology, pp. 223-240.

Yadav, I. S. 1997. Search for quality cultivars, The Hindu, Survey of Indian Agriculture. Pp. 132.

\section{How to cite this article:}

Shaik Jakeer Basha. 2018. Effect of Storage Period on Physio - Chemical Properties of Guava Fruit Leather. Int.J.Curr.Microbiol.App.Sci. 7(04): 1738-1751.

doi: https://doi.org/10.20546/ijcmas.2018.704.198 